
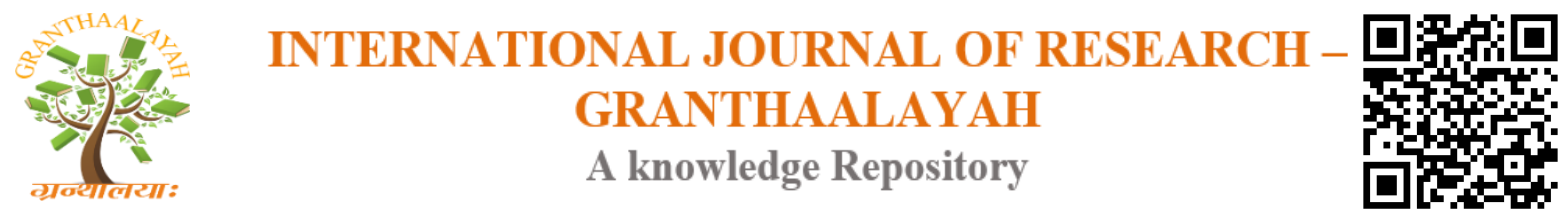

Science

\title{
DYNAMICS OF FRUIT FLIES POPULATIONS IN TWO MANGO PRODUCTION ZONES (KORHOGO AND FERKÉ) IN NORTHERN CÔTE D'IVOIRE
}

\author{
Minhibo Magloire Yves ${ }^{1}$, Akpesse Akpa Alexandre Moïse ${ }^{2}$, Coulibaly Tenon ${ }^{* 3}$, Koua K \\ Hervé $^{2}$, Coulibaly Adama 1 \\ ${ }^{1}$ National Center for Agronomic Research, Station of Korhogo-Lataha, Korhogo, Côte d'Ivoire, \\ 2 Laboratory of Zoology and Animal Biology, UFR-Biosciences, Felix Houphouet-Boigny \\ University, Abidjan, Côte d'Ivoire. \\ 3 Deparment of Animal Biology, UFR Sciences Biologiques, Université Péléforo Gon Coulibaly, \\ BP 1328, Korhogo, Côte d'Ivoire
}

\begin{abstract}
Fruit flies are a major constraint to the production and export of mangoes by causing the rot of mangoes. The objective of this work is to follow the fluctuation of population of flies in the northern part of Côte d'Ivoire between May 2015 and October 2016. A network of trapping flies using food baits (the Torula and Ceratrap) and sexual attractants (Methyl Eugenol and Trimedlure) were set up in Korhogo and Ferké mango orchards with the forest Diabaté Kamonon and the forest Petit Clerc as reference area. During trapping, 11 species of fruit flies were identified at all study sites. Among these species, Bactrocera dorsalis and Ceratitis cosyra, were the most abundant in the area. In general, diversity indices were low. The Ferké's Forest has the highest Shannon index $(H=1.20)$. This index was higher than the index found in Ferke's orchards (0.9398). At Korhogo the Shannon index in orchards $(H=0.84)$ is higher than in the forest $(H=0.41)$. It has been observed that the genus Bactrocera swarmed on mango orchards when precipitation was plentiful. While the genus Cerartitis only appeared when precipitation was low. In addition, knowledge of the ecology and fluctuation of fruit flies, will allow to develop a site monitoring device through a trapping system with sexual and food attractants.
\end{abstract}

Keywords: Mangoes; Flies; Fruits; Dynamics; Fluctuation; Côte d'Ivoire.

Cite This Article: Minhibo Magloire Yves, Akpesse Akpa Alexandre Moïse, Coulibaly Tenon, Koua K Hervé, and Coulibaly Adama. (2019). "DYNAMICS OF FRUIT FLIES POPULATIONS IN TWO MANGO PRODUCTION ZONES (KORHOGO AND FERKÉ) IN NORTHERN CÔTE D'IVOIRE." International Journal of Research - Granthaalayah, 7(7), 256-264. https://doi.org/10.29121/granthaalayah.v7.i7.2019.759. 


\section{Introduction}

The mango, third export fruit of Côte d'Ivoire, generates more than seven billion FCFA per year in Côte d'Ivoire [1]. This crop is threatened by the presence of Tephritidae, of which more than 4,000 species of this family are known throughout the world. They are among the most devastating crop pests in the world [2]. These different species have a wide distribution because they cover the tropical and subtropical zones as well as the temperate zones [3]. Their habitats range from humid forests to dry savannas [4]. Pregnant females sting plant tissues, deposit their eggs on fruit and vegetable species such as citrus fruits, apples, mangos, watermelons, zucchini, tomatoes [5]. Eggs are also observed on Asteraceae family Adventives such as grasses, woody plants and shrubs [6]. Classified as quarantine pests, fruit flies are a limiting factor for fresh fruit and vegetable exports from some countries. In Australia, fruit flies loss from an annual fruit production of $\$ 850$ million is estimated at \$ 100 million [6]. In southwestern Burkina Faso, the damage was higher, estimated at $64 \%$ thanks to the presence of Bactrocera dorsalis on mangoes [7]. In Ivory Coast, Bactrocera dorsalis is responsible for more than $69 \%$ of the damage on mango [8]. In addition to Bactrocera dorsalis, various other species are beginning to appear on mango orchards. The inventory of flies species and the monitoring of their fluctuation is necessary to optimize the fight against these pests.

\section{Materials and Methods}

\subsection{Study Area}

The study was conducted at the National Center for Agronomic Research (CNRA) fruit research station Lataha (Korhogo) $\left(9^{\circ} 34\right.$ 'N and $\left.5^{\circ} 34^{\prime} \mathrm{W}\right)$ and at the CNRA of Ferké. $\left(5^{\circ} 55-3^{\circ} 30 \mathrm{~N}\right.$ and $\left.10^{\circ} 30-8^{\circ} 35 \mathrm{~W}\right)$ : The climate in these two zones is Sudanese with two seasons: a dry season, from November to April, and a rainy season, May to October. Annual precipitation over the last three decades varies between 800 and $1500 \mathrm{~mm}$ with an average temperature ranging between 22 ${ }^{\circ} \mathrm{C}$ and $28^{\circ} \mathrm{C}$. The vegetation consists mainly of savannas with trees and grass. The soils are either ferralitic types derived from granites or shales, or of tropical ferruginous type. The average annual rainfall is $1400 \mathrm{~mm}$ in a wet year and $1000 \mathrm{~mm}$ in the dry year. The natural vegetation consists of savannah trees. The soils are of ferralitic type. Populations of fruit flies were harvested from the orchards of these two stations with natural savanna as the reference area. The plots sampled are as follows: At the two research stations: mango orchards that are full of varieties. The cultivated varieties are "Kent", "Keitt", "Gallery" and "Amelie" with a density of 100 feet per hectare. The reference medium consists of two savannas: In Korhogo, the natural forest of "DIABATE Kamonon" (DK), located to Lataha, has been sampled. (09 ${ }^{\circ} 26.122^{\prime} \mathrm{W}$ and $005^{\circ}$ 08.323 'N) [9]. In Ferké the natural forest of "Petit Clerc" has been sampled $\left(10^{\circ} 26.122 \mathrm{~W}\right.$ and $005^{\circ} 08.323^{\prime} \mathrm{N}$ [10].

\subsection{Sampling Method}

\subsubsection{Characteristic of the Traps}

Three types of traps were used for flies harvesting. These are "TephriTrap" type traps, "McPhailTrap" type traps and local traps. The operating principle of these different traps is as follows: 
Traps of the "Tephri Trap" type are yellow boxes with perforations. The yellow color is recognized as the most attractive for flies. In these traps, closed with a lid, are introduced into the nucelle located under the lid of the trap, parapheromones called "sexual attractants" (Methyl-Eugenol (ME) or Trimedlure (TRI)). These insecticide-associated substances have a similar odor to female flies and specifically attract adult male flies. Sexual attractants, provided in capsule form, have been placed.

"Mc-PhailTrap" type traps are also yellow in color. Three granules of a high-protein liquid food attractant (the "Torula Yeast") were milled and dissolved in $300 \mathrm{ml}$ of water. To this solution was added $3 \mathrm{~g}$ of Borax. Borax has a conservative power and prevents the decomposition of flies captured in the trap [11]. The resulting mixture, combined with an insecticide, was put in each trap. These traps attract male and female flies that come to feed.

Local traps are made locally with plastic bottles. $500 \mathrm{ml}$ of the Ceratrap solution (protein-rich food bait), combined with an insecticide, were taken and placed in each trap. These perforated traps attract both male and female flies.

The insecticide used to kill flies in all these traps was DDVP or Dichlorvos (2,2-dichlorvosvinyl dimethyl phosphate)

\subsubsection{Trapping Device for Flies}

In each mango orchard, just as in the forest zone, the different traps were arranged according to a randomization on three lines. On each line four traps were placed ( 2 were content sexual attractants and 2 others were food attractants). Each line represented a repetition. Each trap was then hooked to a branch of the host plant at a height of about $1.5 \mathrm{~m}$ above the ground [12] away from direct sunlight. The traps were arranged in a square figure or parallelepiped [11]. The branch supporting the trap was covered with solid fat as a barrier to prevent the predatory activity of the ants on adults trapped flies in traps. A total of 12 traps per site were installed. The optimum distance between two lines was about $40 \mathrm{~m}$ to avoid interferences between attractants [13]. The distance between treatments on the same line was 30 m (every 3 trees for orchards).

Each week, flies captured by the traps were collected and a systematic rotation of the traps was performed. Captured flies were counted by trap and then kept in vials containing $70 \%$ alcohol. Precipitation was recorded at each site during the entire trapping period.

\subsubsection{Identification of Flies}

The flies captured in the different traps were identified to the species using identification keys [14, $15,16]$ under a binocular microscope.

\subsection{Data Analysis}

Statistical analysis of the data Ecological indices have been chosen to describe Tephritidae populations. For each medium, the species richness $(\mathrm{S})$, which is the total number of species sampled, was calculated. Then, thanks to the EstimateS software (version 7.0) [17], the Shannon 
index $\left(\mathrm{H}^{\prime}\right)$ and the equitability index $(\mathrm{E})$ were calculated for each area. The abundance of flies (the number of individuals captured per site) was determined and related to rainfall.

\section{Results}

\subsection{Diversity of Tephritidae Caught in Traps}

During trapping, 11 species of fruit flies grouped into genera were identified at all study sites (Table I). They were: Bactrocera dorsalis, Zeugodacus cucurbitae, Ceratitis bremii, C. punctata, C. cosyra, C. capitata, C. anonae, C. fasciventris, Dacus. punctatifrons, D. cilliatus and D. bivatattus. This flies richness was relatively high on all the study plots. Korhogo's forest (Diabaté Kamonon) and the Ferke orchards with 11 harvested species were the most diversified area. Lataha orchards were the least diversified with 8 species harvested. In general, diversity indices were low. Ferké's Forest (Petit Clerck) has the highest Shannon index $(\mathrm{H}=1.20)$. This index was higher than the index found in Ferke's orchards (0.9398). In Korhogo, the Shannon index recorded in the Lataha orchards $(\mathrm{H}=0.84)$ was higher than that of the forest $(\mathrm{H}=0.411)$ considered as the reference area. The highest values of the Simpson Index were obtained in Ferké Forest (0.60), Korhogo Orchards (0.54) and Ferké's Orchards (0.57). This index was low in the Korhogo forest (0.21). Equitability indices were also greater than $50 \%$ on the plots of Ferké's Forest $(0.6683)$, the Korhogo orchards (0.52) and the Ferké orchards (0.5839), reflecting a homogeneous distribution of species in its area. However, the Korhogo Forest recorded the lowest Equitability index (0.23) (Table II).

\subsection{Spatial Variation of Flies' Populations}

A total of 262,965 flies were captured at all four sites. The species B. dorsalis, with a total of 249,763 captured flies, was the most abundant species in both forest and orchards (Table 2). In the Ferké mango tree orchard a total of 67455 individuals were harvested. B. dorsalis and Ceratitis cosyra are the most abundant with 61659 and 4967 flies respectively. In the Ferké natural forest (Petit Clerc), B. dorsalis dominates the stand with an abundance of 36,888 out of a total of 39,166 flies captured on this site. The species C. bremii (747 individuals), C. capitata (569 individuals), C. anonae (356 flies), C. punctata (354 individuals) and C. cosyra (238) are relatively abundant in this environment. In Lataha, in the mango orchard, 101,738 individuals were captured with a large population of B. dorsalis (100,128 flies). In the natural forest area of Lataha (Diabate Kamonon), a total of 51088 individuals of B. dorsalis were recovered from a total of 54600 flies. The species C. punctata (1,430 individuals), C. bremii (765 individuals) and C. cosyra (702 individuals) were least present.

Table I: Diversity index of habitat types

\begin{tabular}{|l|l|l|l|l|}
\hline Localities & Species Richness (S) & Shannon $(\mathbf{H})$ & Equitability (J) & Simpson (1-D) \\
\hline Korhogo's Orchard & 8 & 0,8429 & 0,5237 & 0,5358 \\
\hline Ferké's Orchard & 11 & 0,9398 & 0,5839 & 0,5717 \\
\hline Korhogo's Forest & 11 & 0,411 & 0,229 & 0,207 \\
\hline Ferké's Forest & 10 & 1,198 & 0,6683 & 0,6683 \\
\hline
\end{tabular}


Table II: Abundance of flies species captured by sites

\begin{tabular}{|l|l|l|l|l|}
\hline species & \multicolumn{3}{l|}{ Korhogo } & Ferké \\
\hline & Orchard & Forest & Orchard & Forest \\
\hline Bactrocera dorsalis & 100128 & 51088 & 61659 & 3688 \\
\hline Zeugodacus cucurbitae & 51 & 23 & 116 & 2 \\
\hline Ceratitis cosyra & 562 & 702 & 4967 & 238 \\
\hline Ceratitis bremii & 773 & 765 & 233 & 747 \\
\hline Ceratitis capitata & 77 & 85 & 39 & 569 \\
\hline Ceratitis punctata & 46 & 1430 & 243 & 354 \\
\hline Ceratitis anonae & 84 & 225 & 129 & 356 \\
\hline Ceratitis fasciventris & 0 & 95 & 5 & 1 \\
\hline Dacus bivattatus & 10 & 33 & 12 & 4 \\
\hline Dacus punctatifrons & 7 & 153 & 47 & 7 \\
\hline Dacus ciliatus & 0 & 1 & 5 & 0 \\
\hline
\end{tabular}

\subsection{In the Korhogo Area}

In the mango orchard, B. dorsalis was the most species captured during the sampling period. The most important catches of this fly have been observed from May to September of each year. The maximum fly abundance was captured in June 2015 (11,965 flies) and September 2015 (14,527 individuals) then in June 2016 (18,593 flies). During these months precipitation was also observed in the area (Fig. 1). From the month of October to March of these two years, the population of B. dorsalis has dropped sharply and canceled itself almost in January and February. While the population of other flies species, of which C. cosyra was the most important, has been poorly represented. The number of flies was very low and constant (less than 50 individuals) from July 2015 to April 2016 (Fi. 1). The maximum catch of these flies took place between May and June of each year. This period corresponds to the beginning of the rainy season with average precipitations. In Korhogo's forest area, the catch of B. dorsalis was maximum from June to August of each year with a maximum of 16,683 and 8,579 flies captured, respectively in July 2015 and July 2016. From September on actual captured flies drop to remain constant until the month of March. The number of other flies, of which C. cosyra was the largest, varied in the same order as that of B. dorsalis, but with very low numbers (Fig. 1).

\subsection{In the Ferké Area}

In mango orchard of this area, the capture of B. dorsalis was important from May to July of the two years. The peaks of fly catches were located in June with 19667 and 6436 individuals harvested respectively in 2015 and 2016. During these months we also observed a precipitation in the area. The other flies, including C. cosyra, appeared at the same time, but the numbers are very small. From September to April, total numbers of these species remained relatively low and constant (Figure 1).

In Ferké's forest (Petit Clerc), there was a important catch of B. dorsalis, from May with peaks respectively in June 2015 (12055 individuals) and in July 2016 (4176 individuals). From September 2015, the number of B. dorsalis decreased and remained low until April 2016. The 
abundance of other flies, including C. cosyra, evolved in the same direction as that of B. dorsalis. The peaks of these flies were in January 2016 and in August of the two years (Fi. 1).
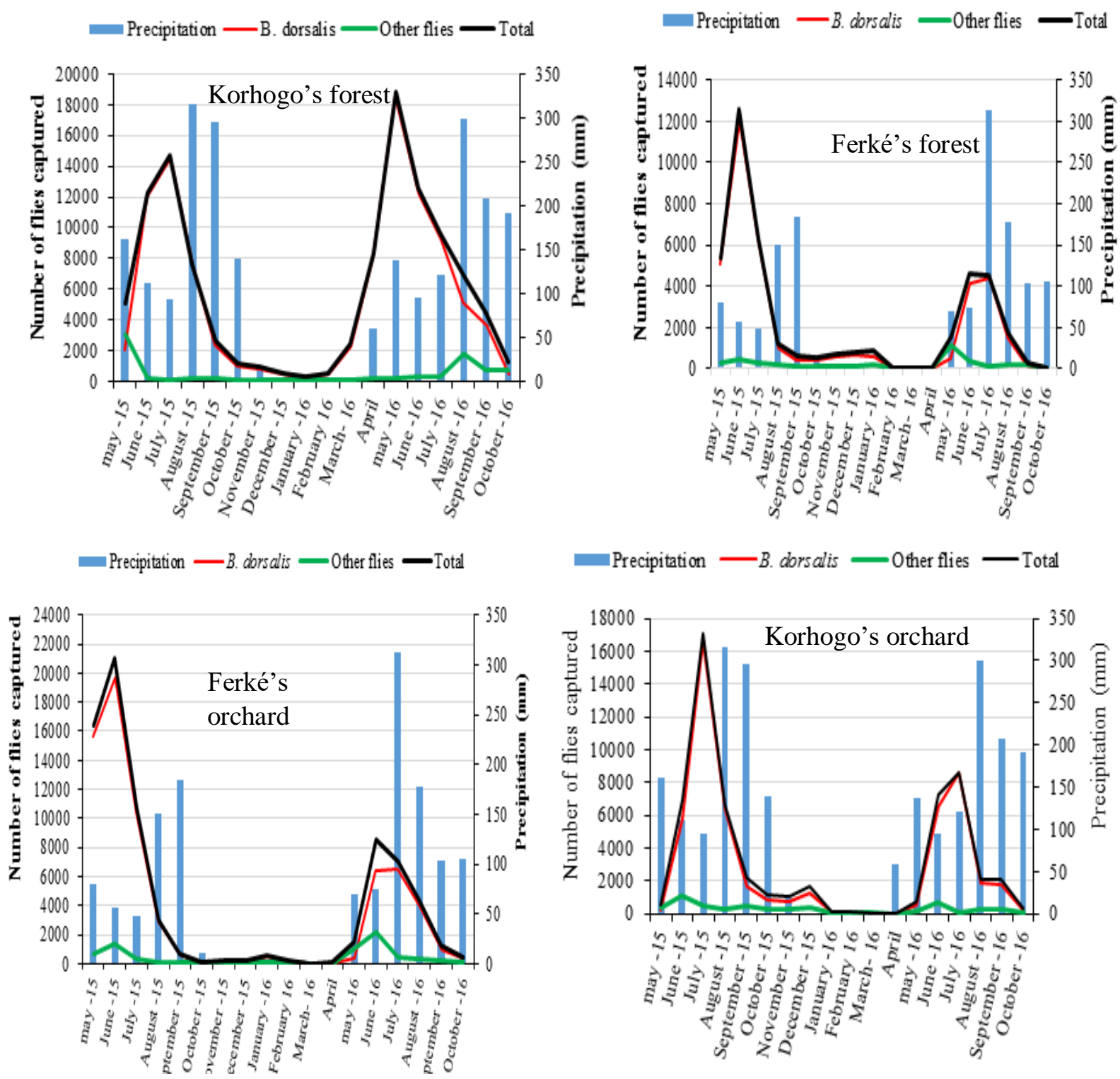

Figure 1: Monthly variation of flies population in Korhogo and Ferké

\section{Discussions}

A total of 11 species of fruit flies grouped into 4 genera were captured by the traps installed. This high diversity was linked to the fact that the study was conducted in two mango production areas, in orchards and in the forest. Most of these species have already been reported in Côte d'Ivoire by the work of [19] but also in other parts of Africa [20, 21]. Of these species of fruit flies harvested, Bactrocera dorsalis appears to be the most important species. This result has also been confirmed by several authors [22, 23, 13]. Native to Asia, Bactrocera dorsalis has spread around the world due to transcontinental trade in fresh vegetables [20]. It would have adapted to the humid and warm climatic conditions so that it developed properly, thus diverting the initial predominance of 
C. cosyra in most parts of West Africa and particularly in Côte d'Ivoire [24]. The abundance of Bactrocera dorsalis observed from May to October in relation to Ceratitis cosyra coincided with the fructification period of the host plants, particularly the mangoes that flies like. The heavy precipitation recorded during these months, accompanied by increase of the relative humidity of the environment, would also explain the abundance of this species. Our work has shown that in all four sites, Bactrocera genus swarms in mango orchards when abundant rainfall while Cerartitis genus appears only when precipitation is low. This observation has been made by several authors $[13,25,19]$. The low proportion of Ceratitis cosyra compared to Bactrocera dorsalis may be explained by inter-lartial food competition and the aggressiveness of adult of B. dorsalis to other species. This situation would cause the displacement of many species to other host plants in the natural environment [26]. The important proportion of fruit flies present in traps in natural forest could be explained by the fact that at the end of the mango season the flies species take refuge in its area.

\section{Conclusions and Recommendations}

Fruit flies influence the production of mangoes in the northern region of Côte d'Ivoire (Korhogo and Ferké). During trapping, 11 species of fruit flies were identified at all study sites. Of these species, Bactrocera dorsalis and Ceratitis cosyra were the most abundant in the area. In general, diversity indices were low. The Ferké's Forest recorded the highest Shannon index $(H=1.20)$. This index was higher than the index found in Ferke's orchards (0.9398). In Korhogo, the Shannon index in the orchards $(\mathrm{H}=0.8429)$ was higher than in the forest $(\mathrm{H}=0.411)$. It has been observed that the genus Bactrocera swarms on mango orchards when precipitation was plentiful. While the genus Cerartitis only appears when precipitation was low. Knowledge of the ecology and fluctuation of fruit flies, will develop a site monitoring device through a trapping system with sexual and food attractants. This monitoring device will provide alerts to trigger the fight against fruit flies.

\section{Acknowledgements}

The authors would like to extend their warmest thanks to the Economic Community of West African States (ECOWAS), the West and Central African Council for Agricultural Research and Development (CORAF/WECARD) and all associated partners for initiating and implementing the project "Support Project for the Regional Plan for the Fight and Control of Fruit Flies in West Africa" and for involving them.

\section{References}

[1] FIRCA, L'importance de l'innovation technologique dans le développement agricole, 2014, 48p

[2] Norrbom, A., Fruit Fly (Diptera: Tephtitidae) Classification and diversity, Systematic and Entomology Laboratory, ARS, USDA, Departement of entomology, NMNH, SI; The Diptera Site, 2004.

[3] Rey, J .Y., Thierno, M. D., Vannière, H., Christian, D., Sidiki, K., \& Morodjan, S., La mangue en Afrique de l'ouest francophone. Fruits, 59, 2004a, 121-129.

[4] Raghu, S., The autecology of Bactrocera cacuminata(Hering) (DipteraTephritidae: Dacinae): Functional significance of resources, Griffith University, Griffith, Australia, PhD Thesis, 2002, 241p. 
[5] Vayssières, J. F., Sinzogan, A. A. C., Korie, S., Ouagoussounon, I., \& Thomas-Odjo, A., Effectiveness of spinosad bait sprays (GF-120) in controlling mango-infesting fruit flies (Diptera: Tephritidae) in Benin. Journal of economicentomology, 102 (2), 2009, 515- 521.

[6] White, I.M., Elson-Harris M., Fruit flies of economic significance: their identification and bionomics. Cab Int., Aciar, Redwood Press, Melksham, UK, 601p, 1992.

[7] Ouedraogo, S. N., Dynamique spatio-temporelle des mouches de fruit Diptera Tephritidae en fonction de facteurs abiotiques et biotiques dans le verger de manguier de l'Ouest du Burkina Faso. Thèse de doctorat spécialité écologie à l'Université Paris Est, 2011, 184p.

[8] N’Dépo, O. R., Hala, N. F., Gnago, A., Allou, K., Kouassi, K. P., Vayssières, J. F., \& De Meyer, M., Inventaire des mouches des fruits de trois régions Agro-écologiques et plantes-hôtes associées à l'espèce nouvelle Bactrocera invadens Drew (Dptera : Tephritidae) en Côte d'Ivoire. European Journal of Scientific Research, 46 (1), 2010, 63-72.

[9] Dominique, L., Sylviculture intense en zone de savane. Atelier sous régional Korhogo, Côte d'Ivoire, 12p, 1990.

[10] Lasm, T., Fossou, N.R.M., Onetie, Z.O., Baka, D., Youan, Ta M., Oga, M.S., \& Soro, N., Contribution hydrogéologique à la connaissance des aquifères discontinus du département de Ferké (nord de la côte d'ivoire) pour une meilleure alimentation en eau potable. Revue Ivoirienne des Sciences et Technologies, 19, 2012,114-135.

[11] Vayssières, J. F., Korie, S., Coulibaly, O., Temple, L. \& Boueyi, S. P., The mangoes tree in nortthem Benin: cultivar inventory, yield assessment,infested stages and loss due to fruit flies (Diptera: Tephritidae) Fruits, vol (63), 2008,1-8.

[12] Barbet, A., Suivi des populations de Ceratitis spp(Diptera: Tephritidae) au nord Côte d'Ivoire dans la perspective d'une lutte raisonnée en verger de manguiers. Mémoire d'Ingénieur des Techniques Agricoles, Montpellier, France, 2000, 52 p.

[13] Vayssières, J.-F., Goergen, G., Lokossou, O., Dossa, P., \& Akponon, C., A new Bactrocera species in Benin among mango fruit fly (Diptera:Tephritidae) species. Fruits, 60, 2005, 371-377.

[14] De Meyer, M., Revision of the subgenus Ceratitis (Pardalaspis) Bezzi, 1918 (Diptera: Tephritidae, Ceratitini). Sytematic Entomology, 21, 1996, 15-26.

[15] De Meyer, M., Revision of the subgenusCeratitis (Ceratalaspis) Hancock (Diptera Tephritidae). Bulletin of Entomology Research, 88, 1998, 257-290.

[16] De Meyer, M., Systematic revision of the subgenus Ceratitis Macleay.sp. (Diptera Tephritidae). Zoological journal of Linnean Society, 128, 2000, 439-467.

[17] Colwell, R. K., 2004. EstimateS: statistical estimation of species richness and shared species from samples. Ver. 7.5. persistent http://purl.oclc.org/estimates. Accessed 12 Apr 2019

[18] N'dépo, O. R., Hala, N. F., Allou, K., Aboua, L. R., Kouassi, K. P., Vayssières, J. F., \& De Meyer, M., Abondance des mouches des fruits dans les zones de production fruitière de Côte d'Ivoire : dynamique des populations de Bactrocera invadens (Diptera : Tephritidae). Fruits, 64 (5), 2009, 313-324.

[19] Mwatawala, M. W., White, I. M., Maerere, P. A., Sekondo, F. J., \& De Meyer, M., A new invasive Bactrocera species (Diptera: Tephritidae) in Tanzania. African Entomology, 12 (1), 2004, 154-156.

[20] Vayssières, J. F., Fatogoma, S., \& Moussa, N., Inventaire des espèces de mouches des fruits (Diptera: Tephritidae) inféodées au manguier au Mali et essai de lutte raisonnée. Fruits, 59(1) 2004, $1-14$.

[21] Ekesi, S., Nderitu, P.W., \& Rwomushana, I., Field infestation, life history and demographic parameters of the fruit fly Bactrocera invadens (Diptera: Tephritidae) in Africa. Bulletin of Entomological Research, 96, 2006, 379-386.

[22] Mwatawala, M. W., de Meyer M., Makundi, R.H., Maerere, A.P., An Overview of Bactrocera ( Diptera Tephritidae ) Invasions and their Speculated Dominancy over Native Fruit Fly Species in Tanzania . Journal of Entomology, 6(1), 2009, 18- 27.

[23] N'Dépo, O., R., Biologie et écologie de Bactrocera invadens. Mémoire de Thèse de Doctorat Unique de l'Université de Cocody-Abidjan, Côte d'Ivoire, 2010. 177p. 
[24] Hala, N. F., Quilici, S., Gnago, A. J., N'dépo, O. R, Kouassi, K. P., \& Allou, K. R.,. Status of fruit flies (Diptera: Tephritidae) in Côte d'Ivoire and implications for mango exports. Proceeding of 7 th International Symposium on Fruit Flies of Economic Importance. 10- 15 September 2006, Salvador, Bahia, Brazil., 2006, 233-239.

[25] Ekesi, S., Billah, M. K., Nderitu, P. W., Lux, A.S., \& Ivan, R., Evidence for competitive displacement of Ceratitis cosyra by the invasive fruit fly Bactrocera invadens (Diptera: Tephritidae) on mango and mechanisms contribution to the displacement. Journal of entomology, 102(3), 2009, 98-991.

*Corresponding author.

E-mail address: yvesminhibo@ gmail.com/tenondezan@ yahoo.fr 